\title{
Mapping pathological phenotypes in reelin mutant mice
}

\author{
Caterina Michetti ${ }^{1,2+}$, Emilia Romano ${ }^{3,4}{ }^{+}$, Luisa Altabella ${ }^{5}$, Angela Caruso ${ }^{1,6}$, Paolo Castelluccio ${ }^{1}$, \\ Gaurav Bedse ${ }^{2}$, Silvana Gaetani ${ }^{2}$, Rossella Canese ${ }^{5 *}$, Giovanni Laviola ${ }^{3 \S}$ and Maria Luisa Scattoni ${ }^{1 * \S}$ \\ ${ }^{1}$ Neurotoxicology and Neuroendocrinology Section, Department of Cell Biology and Neuroscience, Istituto Superiore di Sanità, Rome, Italy \\ 2 Department of Physiology and Pharmacology "V. Erspamer," Sapienza University of Rome, Rome, Italy \\ ${ }^{3}$ Behavioural Neuroscience Section, Department of Cell Biology and Neuroscience, Istituto Superiore di Sanità, Rome, Italy \\ ${ }^{4}$ Bambino Gesù Children's Hospital, Istituto Di Ricovero e Cura a Carattere Scientifico, Rome, Italy \\ ${ }^{5}$ Molecular and Cellular Imaging Section, Department of Cell Biology and Neuroscience, Istituto Superiore di Sanità, Rome, Italy \\ ${ }^{6}$ Department of Psychology, School of Behavioural Neuroscience, Sapienza University of Rome, Rome, Italy
}

Edited by:

Yuri Bozzi, University of Trento, Italy

Reviewed by:

Elizabeth M. Powell, University of Maryland, USA

Emanuel DiCicco-Bloom, University of Medicine and Dentistry of New Jersey, USA

\section{*Correspondence:}

Rossella Canese, Molecular and Cellular Imaging Section, Department of Cell Biology and Neuroscience, Istituto Superiore di Sanità, Viale

Regina Elena 299, I-00161 Rome, Italy e-mail: rossella.canese@iss.it;

Maria Luisa Scattoni, Neurotoxicology and Neuroendocrinology Section Department of Cell Biology and Neuroscience, Istituto Superiore di Sanità, Viale Regina Elena, 299,

I-00161 Rome, Italy

e-mail:marialuisa.scattoni@iss.it

${ }^{\dagger}$ These authors contributed equally to this work.

$\$$ These authors also contributed equally to this work.
Autism Spectrum Disorders (ASD) are neurodevelopmental disorders with multifactorial origin characterized by social communication deficits and the presence of repetitive behaviors/interests. Several studies showed an association between the reelin gene mutation and increased risk of ASD and a reduced reelin expression in some brain regions of ASD subjects, suggesting a role for reelin deficiency in ASD etiology. Reelin is a large extracellular matrix glycoprotein playing important roles during development of the central nervous system. To deeply investigate the role of reelin dysfunction as vulnerability factor in ASD, we assessed the behavioral, neurochemical, and brain morphological features of reeler male mice. We recently reported a genotype-dependent deviation in the ultrasonic vocal repertoire and a general delay in motor development of reeler pups. We now report that adult male heterozygous (Het) reeler mice did not show social behavior and communication deficits during male-female social interactions. Wildtype and Het mice showed a typical light/dark locomotor activity profile, with a peak during the central interval of the dark phase. However, when faced with a mild stressful stimulus (a saline injection) only Het mice showed an over response to stress. In addition to the behavioral studies, we conducted high performance liquid chromatography and magnetic resonance imaging and spectroscopy to investigate whether reelin mutation influences brain monoamine and metabolites levels in regions involved in ASD. Low levels of dopamine in cortex and high levels of glutamate and taurine in hippocampus were detected in Het mice, in line with clinical data collected on ASD children. Altogether, our data detected subtle but relevant neurochemical abnormalities in reeler mice supporting this mutant line, particularly male subjects, as a valid experimental model to estimate the contribution played by reelin deficiency in the global ASD neurobehavioral phenotype.

Keywords: autism spectrum disorders, reeler mice, ultrasonic vocalizations, social interaction, stress response, dopamine, glutamate, circadian cycle

\section{INTRODUCTION}

Autism Spectrum Disorders (ASD) are neurodevelopmental disorders with multifactorial origin characterized by persistent deficits in social communication and interaction and restricted and repetitive patterns of behavior, interests, or activities (1). Several studies showed that abnormal reelin expression in the brain is involved in a number of neuropsychiatric disorders including lissencephaly, schizophrenia, and autism (2-8).

Clinical studies have shown reduced levels of reelin protein in blood serum and in post-mortem brain of ASD patients (9-12). Genetic variants in RELN have been investigated as risk factors of ASD in numerous epidemiologic studies but with inconclusive results (13-19). However, recent data collected on much larger samples and with more advanced genetic approaches indicated a relationship between reelin gene mutation and increase risk of autism, suggesting that reelin deficiency may be a vulnerability factor in the etiology of this neurodevelopmental disorder (20-27).
Animal models in which reelin expression is reduced or absent, provide important information about the role of reelin deficiency in the onset of neurodevelopmental disorders such as ASD. Homozygous reeler mice show decreased brain volume, increased ventricles volume, (28-30), a non-foliated cerebellum (30), reduced number of Purkinje cells (31), deficits in lamination of the hippocampus (Hip), and disorganization of the amygdala (30). Some of these abnormalities are comparable with the ones found in post-mortem studies on autistic brain such as: increased ventricle volume, altered cortical lamination, heterotopias, dysplastic changes, and reduced number of Purkinje cells (32-39). These morphological changes in homozygous reeler mice are also associated with serious physical impairments and for this reason these mice are not considered as a reliable animal model for basic behavioral research but their use has been so far limited to the study of neuronal migration and of etiology of human lissencephaly $(4,5)$. 
Heterozygous reeler mice, which exhibit the $50 \%$ reduction in reelin expression, do not display a reeler phenotype but express a number of abnormal traits including loss of Purkinje cells of the cerebellum $(40,41)$ and decrease in the number of dendritic spines in cortical and hippocampal neurons (42). Reduced levels of reelin are also associated with an increased anxiety profile (43, $44)$, cognitive deficits in the operant conditioning $(44,45)$, executive functions (46), fear conditioning learning $(47,48)$, olfactory conditioning learning (49), latent inhibition (50), and attentional set-shifting (51).

Surprisingly, only limited studies have investigated the contribution of reelin deficiency to the establishment of the social/communicative deficits, first ASD core symptom as indicated in the DSM 5 (1). Adult social responses in heterozygous (Het) reeler mice have been tested so far in two studies assessing either direct male-male and female-female social interactions (52) or performance in a modified version of the three-chamber sociability test (51). In both studies, only social behavioral performances have been assessed but a detailed evaluation of the ultrasonic vocalizations (USVs) emitted during the interaction was missing. To this aim, we deeply investigated the social and vocal repertoire of wildtype (Wt) and Het reeler mice during courtship (53), to evaluate the presence of qualitative alterations in social interaction and communication in this mutant line. In addition, we evaluated the baseline circadian locomotor activity in the home-cage as well as the response to a mild stressful stimulus represented by a saline injection (54-57) to check for abnormalities in the spontaneous locomotor activity that could affect the behavioral performances. To investigate whether reelin mutation influences brain metabolism, brain morphology, and levels of monoamines and their metabolites into selected brain regions involved in ASD and social behavior, we performed in vivo quantitative magnetic resonance imaging (MRI), spectroscopy, and high performance liquid chromatography (HPLC) analyses.

\section{MATERIALS AND METHODS \\ ANIMALS AND HOUSING}

Breeding pairs were originally purchased from The Jackson Laboratory (Bar Harbor, ME, USA) and bred in our laboratory at ISS. About 2 weeks after pairing for breeding ( 15 Het $\times$ Het crosses), the females were individually housed and subsequently inspected daily for pregnancy and delivery. After weaning on postnatal day (pnd) 25, mice were housed by sex in mixed genotype groups (B6C3Fe Wt and Het) of two to three per cage. All mice were housed in a colony room with temperature maintained at $21 \pm 1^{\circ} \mathrm{C}$ and humidity at $60 \pm 10 \%$ with food (Enriched standard diet purchased from Mucedola, Settimo Milanese, Italy) and water available ad libitum. The colony room was maintained on a 12:12 light/dark cycle with lights on at $18.30 \mathrm{~h}$. Mice genotype was determined at pnd 21 by polymerase chain reaction (PCR) analysis on tale samples and the animals were marked by an ear punching for identification. Consistent with the higher prevalence of autism in human males, only male mice were tested. Homozygous reeler mice were not tested due to their serious physical impairments after weaning. The same cohort of adult male mice was tested for male-female reciprocal social interaction with concomitant USVs (3 months of age), locomotor activity in the home-cage
(6 months), and HPLC (7 months). A separate cohort of mice was subjected to in vivo quantitative MRI and spectroscopy at 4 months of age. All procedures were conducted in strict compliance with the European Communities guidelines (EC Council Directive 86/609), Italian legislation on animal experimentation (Decreto L.Vo 116/92).

\section{ADULT MALE-FEMALE SOCIAL INTERACTIONS}

Three-month-old male mice $(N=9 \mathrm{Wt}, N=21 \mathrm{Het})$ were evaluated in the male-female social interaction test as in Ref. (53). Each male subject was isolated $1 \mathrm{~h}$ before testing and the vaginal estrous condition of each stimulus female was assessed as in Ref. (58). Only females in estrous were selected for the test. The unfamiliar stimulus C57BL/6J female mouse was placed into the home-cage of the isolated male mouse and behaviors and USVs were recorded for a 3-min test session. Stimulus mice (C57BL/6J females) were purchased from Jackson Laboratories (Bar Harbor, ME, USA) and maintained in our colony room in social groups of three per home-cage. Each female was used only twice and were matched to the subject mice by age and body weight.

Social interaction test was conducted between 09.00 and $13.00 \mathrm{~h}$, during the dark phase, under red light. In addition to the isolated mouse, the cage contained litter $(1.5-\mathrm{cm}$ deep) and the lid was removed during the test. For video recordings, the videocamera (Panasonic monochrome charge-coupled device camera) was mounted facing the side of the cage and the subsequent scoring of social investigation parameters was conducted with Noldus Observer 10XT software (Noldus Information Technology, Leesburg, VA, USA).

Social interactions were scored from the videotapes for the frequencies and durations of the following behavioral responses performed by the subject mouse: anogenital sniffing (direct contact with the anogenital area), body sniffing (sniffing or snout contact with the flank area), head sniffing (sniffing or snout contact with the head/neck/mouth area), locomotor activity, rearing up against the wall of the home-cage, digging in the bedding, and grooming (self-cleaning, licking any part of its own body). No observations of mounting, fighting, tail rattling, and wrestling behaviors were observed. Scoring was conducted by two investigators uninformed of the genotype. Inter-rater reliability was $98 \%$.

For audio recordings, the ultrasonic microphone (Avisoft UltraSoundGate condenser microphone capsule CM16, Avisoft Bioacoustics, Berlin, Germany) was mounted $20 \mathrm{~cm}$ above the cage and the USVs recorded using Avisoft RECORDER software version 3.2. Settings included sampling rate at $250 \mathrm{kHz}$; format 16 bit. The ultrasonic microphone was sensitive to frequencies between 10 and $180 \mathrm{kHz}$. For acoustical analysis, recordings were transferred to Avisoft SASLabPro (version 4.40) and a fast Fourier transformation (FFT) was conducted as previously described (59). Start times for the video and audio files were synchronized. Parameters analyzed included number and mean duration of calls, qualitative and quantitative analyses of sound frequencies measured in terms of frequency, and amplitude at the maximum of the spectrum. Waveform patterns of calls [a total of 17195 (Wt) and 8454 (Het) calls] were examined in depth in the sonograms collected from every mouse tested. Each call was identified as one of eight distinct categories, based on internal 
pitch changes, lengths, and shapes, as in our previously published studies $(53,59,60)$.

Inter-rater reliability in scoring the call categories was $98 \%$. Scoring was conducted by two investigators blind to the mouse genotype. Call category data were subjected to two different analyses: (1) Genotype-dependent effects on the probability of producing calls (proportion of calls in each category for each subject) from each of the eight categories of USV, as described below under statistical analysis; (2) a descriptive analysis that included genotype-dependent effects on the percentage of calls emitted by each subject in each of the eight categories of USV.

\section{LOCOMOTOR ACTIVITY IN THE HOME-CAGE}

At 6 months of age, male mice $(N=9 \mathrm{Wt}, N=10 \mathrm{Het})$ were individually housed in standard cages $(33 \mathrm{~cm} \times 13 \mathrm{~cm} \times 14 \mathrm{~cm})$ and assigned to a continuous monitoring of spontaneous locomotor activity. The assessment of daily spontaneous activity in the home-cage was carried out by means of an automatic device using small passive infrared sensors positioned on the top of each cage (Activiscope system, see the website: www.newbehavior.com) (61-63). The system operated continuously for 13 days and after 2 days of acclimation the experimental procedure began. The sensors $(20 \mathrm{~Hz})$ detected any movement of mice. Data were recorded by an IBM computer with dedicated software. No movements were detected by the sensors when mice were sleeping, inactive, or performed moderate self-grooming. Scores were obtained during 30-min intervals and expressed as counts per minute (cpm). The 24-h profile of activity was obtained by averaging 7 days of continuous registration. The position of Wt and Het mouse cages in the rack was equally distributed in rows and columns. Animals were provided with tap water and food pellets ad libitum. After the first 7 days of spontaneous activity, all animals were subjected to an injection of saline (a mild stressful stimulus), at $11 \mathrm{~h}$ (dark phase), and locomotor activity monitored up to 3 days later. The analysis of the locomotor profile over a period of $7 \mathrm{~h}(11-18)$ after saline injection was performed to evaluate the immediate stress response.

\section{MONOAMINES AND THEIR METABOLITES: HPLC DETERMINATION}

Subsequently to behavioral studies, male mice $(N=9 \mathrm{Wt}, N=10$ Het) were sacrificed, their brains removed and rapidly dissected on ice to obtain the olfactory bulb, frontal cortex, striatum, Hip, and cerebellum for HPLC analysis. All samples were immediately flash frozen on dry ice, and then stored at $-80^{\circ} \mathrm{C}$ until further processing. HPLC was performed according to Ref. (64). In particular, each brain region was weighed, ultrasonicated in $0.1 \mathrm{M}$ perchloric acid, centrifuged for $20 \mathrm{~min}$ at $15,000 \mathrm{~g}\left(4^{\circ} \mathrm{C}\right)$ and the supernatant was used for monoamine neurotransmitters and their metabolites detection. The endogenous levels of 5-HT and 5-HT metabolite (5-hydroxyindolacetic acid; 5HIAA), dopamine (DA) and final DA metabolite (homovanillic acid; HVA), and norepinephrine (NA) and NA metabolite (4-hydroxy-3-methoxyphenyl-glycol, MOPEG) were assayed by HPLC using a SphereClone $150 \mathrm{~mm} \times 2 \mathrm{~mm}$ column $(3-\mu \mathrm{m}$ packing). Detection was accomplished with a Unijet cell (BAS) with a 6-mm-diameter glassy carbon electrode at $+650 \mathrm{mV}$ versus an $\mathrm{Ag} / \mathrm{AgCl}$ reference electrode, connected to an electrochemical amperometric detector (INTRO, Antec Leyden, The Netherlands). For each analysis, a set of standards containing various concentrations of each compound (monoamines and their metabolites) was prepared in the perchloric acid solution, and calibration curves were calculated by a linear regression. The retention time of calibration standards was used to identify peaks, and areas under each peak were used to quantify monoamine levels. Results were normalized to the weight of wet tissue.

\section{MAGNETIC RESONANCE IMAGING AND SPECTROSCOPY}

At 4 months of age, a separate cohort of male mice $(N=7 \mathrm{Wt}$, $N=7$ Het), was subjected to in vivo MRI and magnetic resonance spectroscopy (MRS). During the MR analyses, animals were anesthetized with $2.5-2.0 \%$ isoflurane in oxygen $1 \mathrm{l} / \mathrm{min}$ (Isoflo, Abbott SpA, Latina, Italy). An integrated heating system allowed maintaining the animal body temperature at $37.0 \pm 0.1^{\circ} \mathrm{C}$. All MRI and MRS experiments were conducted on a $4.7 \mathrm{~T}$ Varian/Agilent Inova animal system (Agilent Inc., Palo Alto, CA, USA), equipped with actively shielded gradient system $(\max 200 \mathrm{mT} / \mathrm{m}, 12 \mathrm{~cm}$ bore size). A 6-cm diameter volume coil was used for transmission in combination with an electronically decoupled receive-only surface coil (Rapid Biomedical, Rimpar, Germany). Spin-echo sagittal anatomical images $(\mathrm{TR} / \mathrm{TE}=3000 / 60 \mathrm{~ms}, 13$ consecutive slices of $0.8 \mathrm{~mm}$ thickness, $\mathrm{FOV}=20 \mathrm{~mm} \times 20 \mathrm{~mm}$, matrix of $128 \times 128$, 2 averages) were acquired for accurate positioning the voxel for the MRS study. Single voxel localized ${ }^{1} \mathrm{H}$ MR spectra (PRESS, $\mathrm{TR} / \mathrm{TE}=4000 / 23 \mathrm{~ms}$, $\mathrm{ns}=256$ or 512$)$ were collected from relevant brain areas: Hip $(11.7 \mu \mathrm{l})$, striatum (STR, $10.4 \mu \mathrm{l})$, thalamus (Th, $12.96 \mu \mathrm{l})$, and cerebellum $(\mathrm{Cb}, 7.45 \mu \mathrm{l})$, as shown in Figure 1A and defined in the mouse brain atlas (65). Quantitative MRS protocol, including water T2 measurements, was applied (66) and T2 measurements were performed on water signal in order to identify any change in the mutant mice. Unsuppressed water signal was used for metabolite quantification (assuming $79.9 \%$ for gray matter water content). Spectra were analyzed using LCModel (67). Only those metabolites that were estimated to have Cramer-Rao lower bounds (CRLB) $<20 \%$, which corresponded to an estimated concentration error $<0.2 \mu \mathrm{mol} / \mathrm{g}$, were included into the quantitative analysis. In some cases, metabolites that have resonance overlapped or very close are also given as their sum. An example of spectra and its LCModel analysis is shown in Figure 1B.

Multislice fast spin-echo axial images (TR/TEeff $=3200 / 60 \mathrm{~ms}$, $\mathrm{ns}=4$, slice thickness $0.6 \mathrm{~mm}, 24$ slices, matrix $256 \times 256$, FOV $=25 \mathrm{~mm} \times 25 \mathrm{~mm}$, which correspond to voxel resolution of $98 \times 98 \times 600 \mu^{3}$ ) were also acquired for volumetric analyses.

Motor cortex thickness was measured at +1.32 from bregma as shown in Figure 1C. Volumetric analyses of the whole brain have been performed from olfactory bulb to cerebellum excluded. Ventricles and cerebellum volumes were also measured. Brains were manually segmented for forebrain, ventricles, and cerebellum using Varian/Agilent Imaging Browser, which perform a 3Dvolume calculation by summing the pixels areas on the center of each slices and interpolating the cross sectional areas between the center of the other slices (Agilent Inc., Palo Alto, USA) on MR images. Manual segmentation of the ventricles was facilitated by 


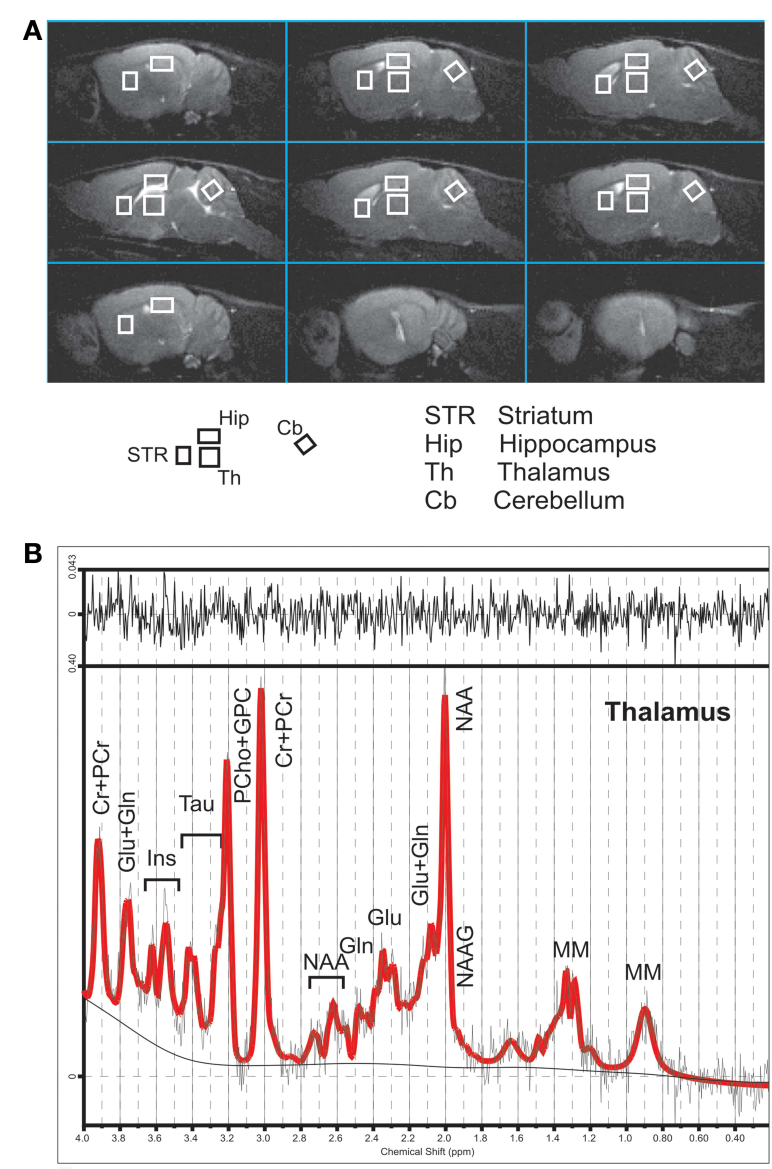

FIGURE 1 | Magnetic resonance imaging and spectroscopy performed in 4-month-old reeler mutant mice. (A) MRI panel - example of in vivo sagittal T2-weighted spin-echo images (TR/TE $=3000 / 70 \mathrm{~ms}$, slice thickness $0.8 \mathrm{~mm}, \mathrm{NS}=2, \mathrm{FOV}=20 \mathrm{~mm} \times 20 \mathrm{~mm}$, matrix $128 \times 128)$. Voxels localized on STR, Hip, Th, and $\mathrm{Cb}$ are indicated by the white rectangles. (B) MRS panel - examples of in vivo $1 \mathrm{H}$ spectra (as a black trace), acquired from the thalamus (PRESS, TR/TE $=4000 / 23 \mathrm{~ms}, \mathrm{NS}=256$ ). The result of LCModel fit is shown as a red trace superimposed on the spectrum. Metabolite assignments: Ins, inositol; $\mathrm{Cr}$, creatine; $\mathrm{PCr}$, phospho-creatine; Glu, glutamate; GIn, glutamine; Tau, taurine; PCho, phospho-choline; GPC, glicero-phospho-choline; NAA, N-acetyl-aspartate; NAAG,
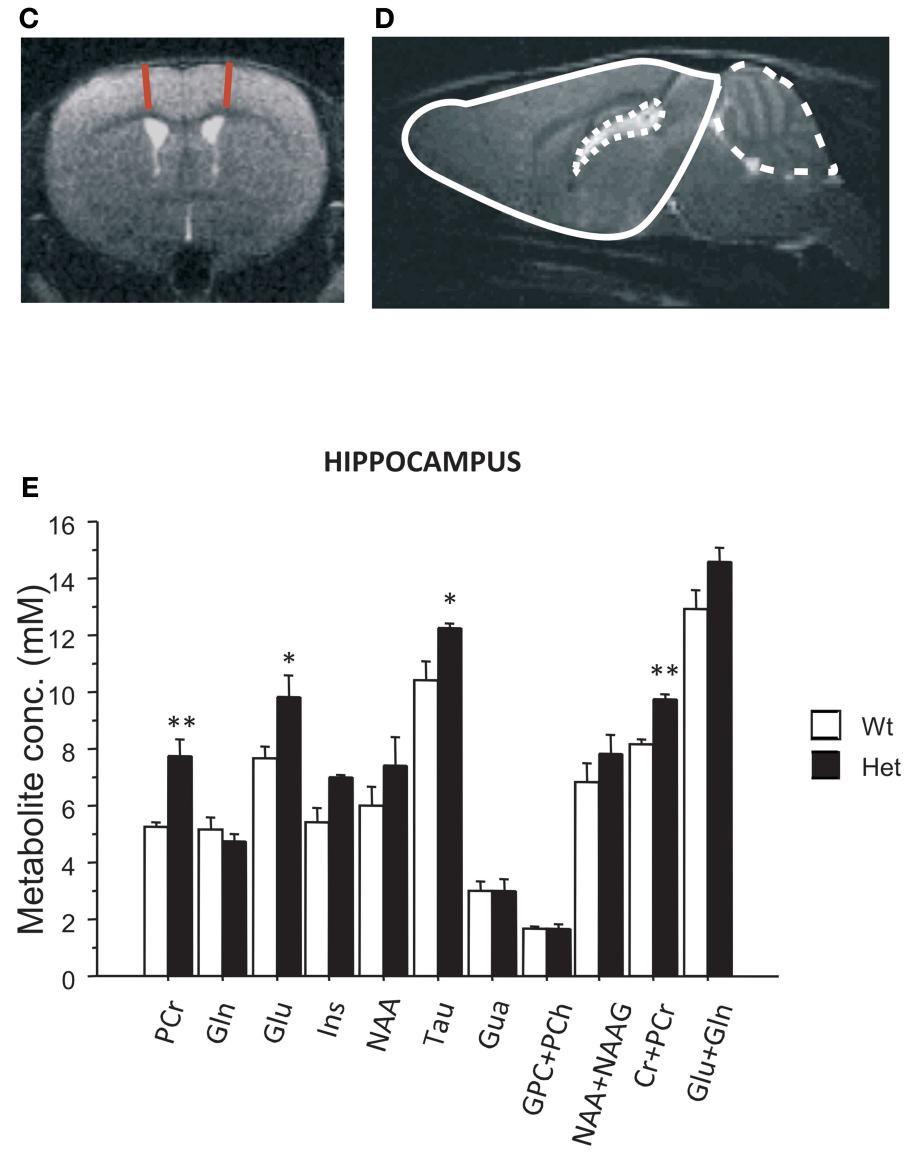

$\mathrm{N}$-acetyl-aspartyl-glutamate; MM, macromolecules. (C) Examples of axial fast T2-weighted MR images from reeler heterozygous (Het) mice, respectively (TR/TEeff $=3200 / 60 \mathrm{~ms}$, $\mathrm{ns}=4$, slice thickness $0.6 \mathrm{~mm}, 24$ slices, matrix $256 \times 256$, FOV $=25 \mathrm{~mm} \times 25 \mathrm{~mm}$, which correspond to voxel resolution of $\left.98 \times 98 \times 600 \mu \mathrm{m}^{3}\right)$. The red lines show the motor cortex thickness measure. (D) Example of brain segmentation for volumetric analyses of brain (plain line), cerebellum (dashed line), and ventricles (dotted line). (E) The histogram shows metabolite concentrations in hippocampus (Hip) for the two groups. Data are expressed as mean + SEM, ${ }^{*} P<0.05$, ${ }^{*} P<0.005$ between wildtype and heterozygous reeler mice. $N=7 \mathrm{Wt}$ and $N=7 \mathrm{Het}$

Data relative to MRI and MRS were analyzed by a one way ANOVA with genotype as the independent factor and MRI/MRS parameters (values of water T2, metabolite levels in each brain region and volume of each brain region) as dependent factor. Differences between genotypes in each brain region with respect to serotoninergic, dopaminergic, and noradrenergic systems (5HT, 5-HIAA, and 5-HT turnover for serotoninergic system; DA, HVA, DOPAC, and DA turnover for dopaminergic system; and NA, MOPEG, and NA turnover for noradrenergic system) were determined by a multivariate analysis of variance (MANOVA), due to the potentially high correlation between these dependent variables within each system. Pillai's statistic was used. Univariate ANOVAs were conducted for each variable (Statview II, Abacus Concepts, CA, USA). 
For all comparisons, data are expressed as mean \pm SEM and significance was set at $P<0.05$. Post hoc comparisons were performed using Tukey's test only when a significant $F$-value was determined.

\section{RESULTS}

\section{MALE-FEMALE SOCIAL INTERACTION TEST}

To assess the presence or absence of a social communication deficit in Het reeler mice, we evaluated the behaviors and the USVs emitted by a male mouse during the interaction with an estrus C57BL/6J female. Analysis of the social sniffing response on different body areas (head, body, and anogenital) did not reveal significant effects of genotype [frequency, $F(2,56)=0.15, P=0.858$, (data not shown); duration, $F(2,56)=1.74 ; P=0.183$, Figure 2A]. No genotype effect was detected on explorative behaviors such as rearing [frequency, $F(1,28)=0.27, P=0.610$ and duration, $F(1,28)=0.30, P=0.589$ ] and digging [frequency, $F(1,28)=0.75$, $P=0.392$ and duration, $F(1,28)=1,15, P=0.292$ ] (data not shown).

Analysis of the USVs emitted by male mice during the social interaction test did not detect significant differences between Het reeler and Wt mice: number of USVs [number of calls $\times$ genotype, $F(2,56)=0.89, P=0.41$, Figure $2 \mathrm{~B}$ ], mean duration $[F(2,54)=0.79, P=0.457$ (data not shown)], peak frequency $[F(2,54)=0.43, P=0.650$ (data not shown)], and peak amplitude $[F(2,54)=0.14, P=0.863$ (data not shown) $]$. As a whole, the pattern of sonographic structures did not differ between Het reeler and Wt mice indicating a comparable vocal repertoire in both genotypes (see pie graphs in Figure 2C).

\section{LOCOMOTOR ACTIVITY IN THE HOME-CAGE}

Sleep problems and irregular sleep-wake cycles have been identified in several ASD children (68-71). Alterations in circadian rhythm lead to anxiety-like, impulsive, and depressive behaviors both in humans and mice (72-74). In the present study, we evaluated baseline circadian locomotor activity in the home-cage as well as response to a mild stressful stimulus represented by a saline injection to check for abnormalities in the spontaneous locomotor activity that could affect the behavioral performances.

Analysis of spontaneous locomotor activity measured in the home-cage for 7 days revealed, as expected, an increased activity in mice of both genotypes during the dark phase of the light/dark cycle [phase effect, $F(1,17)=239.05, P<0.001$ ] (see Figure 3 ). No genotype differences were found [light phase: genotype, $F(1,17)=2.99, P=0.102$; dark phase: genotype, $F(1,17)=1.34$, $P=0.263$.

The analysis of the locomotor profile over a period of $7 \mathrm{~h}$ after saline injection (11-18, dark phase) was performed to evaluate the immediate stress response. Het reeler mice increased significantly their locomotor activity as compared to $\mathrm{Wt}$ mice [genotype, $F(1,17)=5.63, P=0.029$ ] thus revealing a genotypedependent increased sensitivity to mild stress challenge (see graph on the top right of Figure 3). After this 7-h-period, locomotor activity goes back to the normal activity profile [genotype effect, $F(1,17)=0.226, P=0,64$; genotype $\times$ hours, $F(1,23)=0.38, P=0.99$; data not shown].
A

\section{Sniffing duration}

Wt $\square$ Het

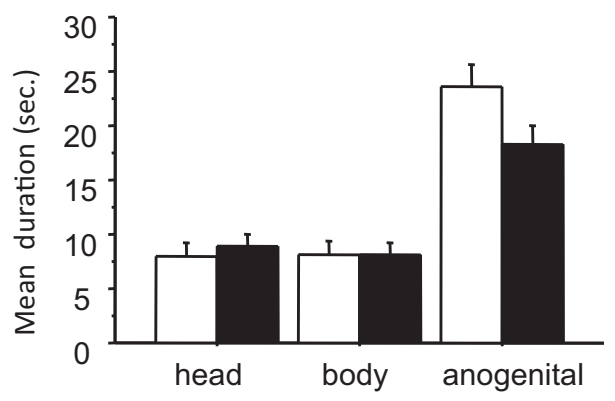

B Number of USVs

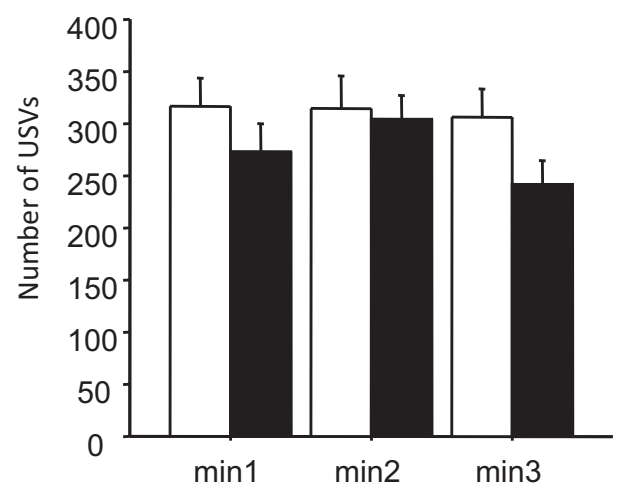

c Categories of calls
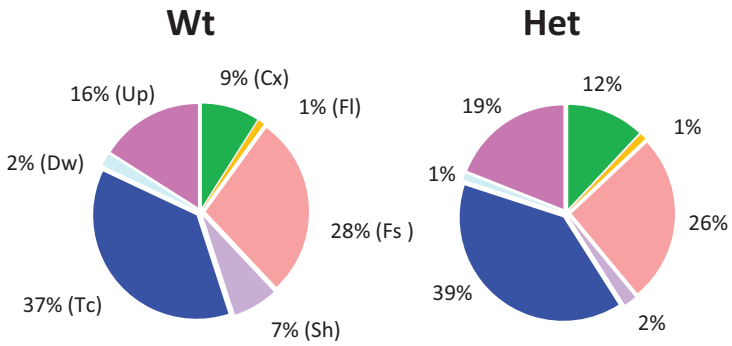

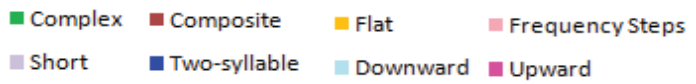

FIGURE 2 | Male-female social interaction test (3-min-session) performed in 3-month-old reeler mutant mice. Parameters measured during a direct interaction between a male with a sexually receptive C57BL/6J female. (A) Sniffing duration. (B) Number of ultrasonic vocalizations. Data are expressed as mean + SEM. (C) Pie graphs show the percentages of the different call categories emitted by Wt and Het reeler mice. Percentages were calculated in each genotype as number of calls in each category for each subject/total number of calls analyzed for each subject. Number of calls analyzed: 17195 in Wt and 8454 in Het. N=9 Wt and $N=21 \mathrm{Het}$. 


\section{Locomotor activity after injection}

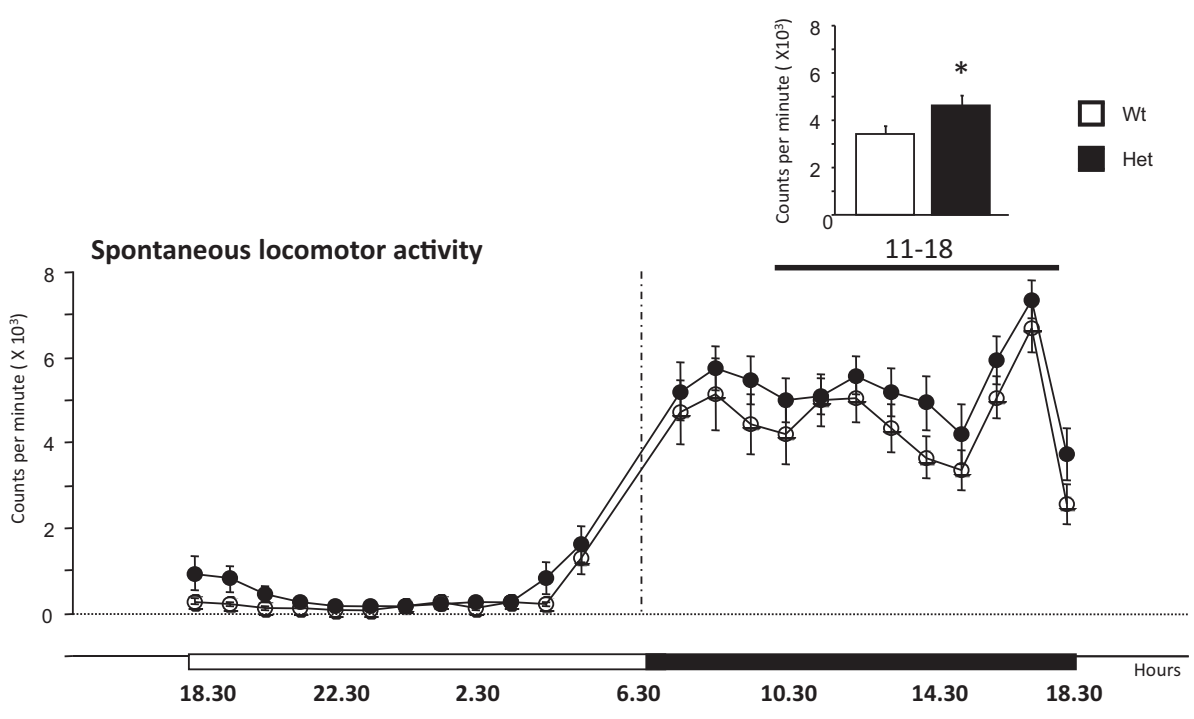

FIGURE 3 | Locomotor activity expressed spontaneously in the home-cage by 6-month-old wildtype and heterozygous reeler male mice. The main graph indicates spontaneous locomotor activity monitored for 1 week. The graph on the top right shows the spontaneous locomotor activity monitored for $7 \mathrm{~h}$ after a mild stressful stimuli represented by a saline injection at $11 \mathrm{~h}$ (dark phase). Data are expressed as mean $\pm \mathrm{SEM}$, ${ }^{*} P<0.05$, between wildtype and heterozygous reeler mice. $N=9 \mathrm{Wt}$ and $N=10$ Het.

\section{MONOAMINES AND THEIR METABOLITES: HPLC DETERMINATION}

High performance liquid chromatography determination has been applied to investigate whether reelin mutation influences the different monoamine systems. MANOVA revealed a significant genotype effect on several components of the dopaminergic system in hypothalamus [Pillai's Trace: $F(4,13)=9.73, P<0.001$ ] and in Hip [Pillai's Trace: $F(4,13)=4.97, P=0.005$ ]. ANOVA showed a strong reduction of DA levels [genotype effect, $F(1,16)=5.29$, $P=0.035$ ] and a consequent increase in the DA turnover [genotype effect, $F(1,16)=7.43, P=0.015]$ in the cortex of Het reeler as compared to Wt mice (see Table 1). Moreover, Het reeler mice showed an increase of DOPAC and HVA levels [genotype effect: DOPAC, $F(1,16)=18.88, P<0.001$; HVA, $F(1,16)=11.47$, $P=0.003]$ in hypothalamus. ANOVA evidenced also a decrease of HVA levels $[F(1,16)=6.43, P=0.022]$ and an increase of DA turnover [genotype effect, $F(1,16)=6.14, P=0.025$ ] in Hip of Het mice.

Heterozygous mice showed an higher DA levels [genotype effect, $F(1,16)=4.38, P=0.052$ ] and a lower DA turnover in olfactory bulb [genotype effect, $F(1,16)=6.87, P=0.018$ ] than Wt mice. No genotype related differences were found on noradrenergic and serotoninergic systems in each brain areas analyzed.

\section{MAGNETIC RESONANCE IMAGING}

To acquire deeper information into the functional state of brain areas involved in ASD, we assessed a ${ }^{1} \mathrm{H}$ magnetic resonance in adult reeler male mice. Enlarged ventricles and reduced cerebellum are typical features of reeler mice (75). Volumetric analyses confirmed a cerebellum reduction [genotype effect, $F(1,10)=15.50$, $P=0.002$ ] and an enlargement of ventricles volume [genotype effect, $F(1,11)=8.01, P=0.016]$ in Het reeler when compared to
Wt mice. No genotype differences were detected in volume [genotype effect, $F(1,11)=0.86, P=0.374]$ and medial motor cortex (MC) thickness [genotype effect, $F(1,11)=3.62, P=0.083$ ] (see Table 2).

\section{MAGNETIC RESONANCE SPECTROSCOPY}

To investigate the possible alterations in brain metabolism of adult reeler male mice, we performed MRS. The high quality spectra allowed reliable quantification $(\% \mathrm{SD}<20 \%)$ not only for the commonly observed $N$-acetyl-aspartate (NAA), total creatine $(\mathrm{Cr}+\mathrm{PCr})$ and total choline resonances (NAA + NAAG), but also for glutamine (Gln), glutamate (Glu), taurine (Tau), and inositol (Ins) in all the investigated brain regions.

Water T2 analyses confirmed that no changes between the genotypes occurred in the T2s in Hip $[F(1,10)=2.52, P=0.143]$, Striatum $[F(1,10)=0.02, P=0.883]$, Thalamus $[F(1,10)=1.15 \mathrm{E}-5$, $P=0.977]$, and Cerebellum $[F(1,10)=0.32, P=0.584]$ (data not shown).

Metabolic changes were detected in Hip while no differences have been found for any metabolite in thalamus, striatum, and cerebellum. Het reeler mice showed increased levels of Glu [genotype effect, $F(1,11)=4.61, P=0.044$ ], Tau [genotype effect, $F(1,11)=4.82, P=0.050$ ], PCr [genotype effect, $F(1,7)=18.08$, $P=0.003$ ], and total amount of $\mathrm{PCr}+\mathrm{Cr}$ [genotype effect, $F(1,11)=24.68, P<0.001]$ in Hip as compared to Wt mice (see Figure 1E).

\section{DISCUSSION}

Reelin is a glycoprotein playing a crucial role during development: it regulates neuronal migration and brain lamination $(6,8,29$, $30,76,77)$ and its reduced or complete lack of signaling impairs 
Table 1 | Levels of monoamines and their metabolites detected ex vivo in cortex, bulbs, hypothalamus, striatum, hippocampus, and cerebellum (mean \pm SEM: picogram per milligram of wet tissue).

\begin{tabular}{|c|c|c|c|c|c|c|c|c|}
\hline \multirow[t]{3}{*}{ Brain region } & \multirow[t]{3}{*}{ Genotype } & \multicolumn{7}{|c|}{ Neurotransmitter, metabolite concentration picogram per milligram wet brain weight) } \\
\hline & & \multicolumn{2}{|c|}{ Noradrenergic system } & \multicolumn{3}{|c|}{ Dopaminergic system } & \multicolumn{2}{|c|}{ Serotoninergic system } \\
\hline & & NA & MOPEG & DA & DOPAC & HVA & 5-HT & 5-HIAA \\
\hline \multirow[t]{2}{*}{ Cortex } & Wt & $469.60 \pm 22.99$ & $102.74 \pm 7.53$ & $874.14 \pm 268.95$ & $134.50 \pm 19.85$ & $252.97 \pm 35.58$ & $523.10 \pm 29.72$ & $341.42 \pm 17.59$ \\
\hline & Het & $440.84 \pm 28.76$ & $102.47 \pm 6.20$ & $296.37 \pm 69.32^{*}$ & $108.65 \pm 18.65$ & $184.52 \pm 40.76$ & $470.09 \pm 31.15$ & $285.37 \pm 14.32$ \\
\hline \multirow[t]{2}{*}{ Bulbs } & $W_{t}$ & $291.82 \pm 24.28$ & $46.35 \pm 5.94$ & $312.11 \pm 33.66$ & $100.26 \pm 8.63$ & $152.87 \pm 15.49$ & $247.65 \pm 25.63$ & $191.88 \pm 16.88$ \\
\hline & Het & $346.10 \pm 14.98$ & $66.26 \pm 6.28$ & $396.15 \pm 23.84^{*}$ & $102.06 \pm 6.83$ & $154.78 \pm 8.95$ & $131.53 \pm 20.97$ & $192.13 \pm 9.76$ \\
\hline \multirow[t]{2}{*}{ Hypothalamus } & $W_{t}$ & $1789.74 \pm 80.36$ & $205.08 \pm 23.06$ & $394.87 \pm 16.83$ & $116.63 \pm 6.12$ & $362.10 \pm 13.19$ & $518.33 \pm 22.43$ & $934.82 \pm 42.78$ \\
\hline & Het & $1742.52 \pm 81.41$ & $183.74 \pm 7.50$ & $540.86 \pm 163.65$ & $144.44 \pm 5.48^{* *}$ & $444.55 \pm 13.27^{* *}$ & $487.36 \pm 29.79$ & $864.22 \pm 19.73$ \\
\hline \multirow[t]{2}{*}{ Striatum } & $W_{t}$ & $129.71 \pm 32.78$ & $339.05 \pm 49.89$ & $12521.13 \pm 1661.54$ & $2718.95 \pm 326.72$ & $4310.08 \pm 383.59$ & $453.07 \pm 30.88$ & $654.30 \pm 23.09$ \\
\hline & Het & $128.12 \pm 19.16$ & $261.70 \pm 25.90$ & $12275.97 \pm 1376.40$ & $2847.63 \pm 196.75$ & $4583.34 \pm 398.19$ & $109.34 \pm 26.48$ & $679.84 \pm 24.65$ \\
\hline \multirow[t]{2}{*}{ Hippocampus } & Wt & $508.02 \pm 33.64$ & $115.37 \pm 6.77$ & $82.16 \pm 7.61$ & $18.21 \pm 1.33$ & $69.47 \pm 8.48$ & $505.52 \pm 61.78$ & $540.99 \pm 37.90$ \\
\hline & Het & $423.67 \pm 39.12$ & $108.17 \pm 8.75$ & $84.80 \pm 13.48$ & $25.16 \pm 4.81$ & $42.01 \pm 6.93^{*}$ & $580.54 \pm 33.18$ & $503.31 \pm 53.05$ \\
\hline \multirow[t]{2}{*}{ Cerebellum } & Wt & $402.46 \pm 28.48$ & $48.85 \pm 3.12$ & $5.09 \pm 1.06$ & $12.52 \pm 2.38$ & $80.66 \pm 5.09$ & $115.60 \pm 17.51$ & $129.05 \pm 6.03$ \\
\hline & Het & $433.56 \pm 17.08$ & $46.17 \pm 3.42$ & $6.75 \pm 2.68$ & $18.77 \pm 7.55$ & $79.52 \pm 3.59$ & $118.94 \pm 21.13$ & $126.85 \pm 6.04$ \\
\hline \multirow[t]{2}{*}{ Brain region } & Genotype & \multicolumn{3}{|c|}{ Neurotransmitter turnover } & & & & \\
\hline & & NA & DA & 5-HT & & & & \\
\hline \multirow[t]{2}{*}{ Cortex } & Wt & $0.22 \pm 0.01$ & $0.24 \pm 0.05$ & $0.66 \pm 0.03$ & & & & \\
\hline & Het & $0.24 \pm 0.01$ & $0.45 \pm 0.05^{*}$ & $0.62 \pm 0.03$ & & & & \\
\hline \multirow[t]{2}{*}{ Bulbs } & $W_{t}$ & $0.16 \pm 0.02$ & $0.33 \pm 0.02$ & $0.80 \pm 0.05$ & & & & \\
\hline & Het & $0.19 \pm 0.01$ & $0.26 \pm 0.02 *$ & $0.86 \pm 0.05$ & & & & \\
\hline \multirow[t]{2}{*}{ Hypothalamus } & Wt & $0.11 \pm 0.01$ & $0.30 \pm 0.02$ & $1.81 \pm 0.09$ & & & & \\
\hline & Het & $0.11 \pm 0.01$ & $0.35 \pm 0.04$ & $1.83 \pm 0.11$ & & & & \\
\hline \multirow[t]{2}{*}{ Striatum } & Wt & $4.09 \pm 1.01$ & $0.23 \pm 0.03$ & $1.47 \pm 0.06$ & & & & \\
\hline & Het & $2.86 \pm 0.7 \mathrm{E}$ & $0.26 \pm 0.03$ & $1.71 \pm 0.10$ & & & & \\
\hline \multirow[t]{2}{*}{ Hippocampus } & Wt & $0.23 \pm 0.01$ & $0.23 \pm 0.02$ & $0.95 \pm 0.11$ & & & & \\
\hline & Het & $0.26 \pm 0.02$ & $0.29 \pm 0.02 *$ & $0.87 \pm 0.07$ & & & & \\
\hline \multirow[t]{2}{*}{ Cerebellum } & Wt & $0.12 \pm 0.01$ & $2.83 \pm 0.51$ & $1.25 \pm 0.13$ & & & & \\
\hline & Het & $0.11 \pm 0.01$ & $6.76 \pm 2.45$ & $1.36 \pm 0.23$ & & & & \\
\hline
\end{tabular}

${ }^{*} P<0.05,{ }^{*} P<0.005$ between wildtype and heterozygous reeler mice. 
Table 2 | Analysis for forebrain, cerebellum, and ventricles volume

\begin{tabular}{lllll}
\hline & $\begin{array}{l}\text { Forebrain } \\
\text { volume }(\boldsymbol{\mu} \mathbf{1})\end{array}$ & $\begin{array}{l}\text { Ventricles } \\
\text { volume }(\boldsymbol{\mu} \mathbf{1})\end{array}$ & $\begin{array}{l}\text { Cerebellum } \\
\text { volume }(\boldsymbol{\mu} \mathbf{1})\end{array}$ & $\begin{array}{l}\text { Medial cortex } \\
\text { thickness }(\mathbf{m m})\end{array}$ \\
\hline $\mathrm{Wt}$ & $366.17 \pm 2.6$ & $3.29 \pm 0.5$ & $59.18 \pm 1.2$ & $1.16 \pm 0.1$ \\
Het & $369.85 \pm 3.0$ & $5.25 \pm 0.4^{*}$ & $53.03 \pm 1.1^{*}$ & $1.22 \pm 0.1$ \\
\hline
\end{tabular}

Data are expressed as mean \pm SEM. ${ }^{*} P<0.05$, between wildtype and heterozygous reeler mice.

neuronal connectivity and synaptic plasticity $(43,78)$. Moreover, recent data suggest that a defect in reelin signaling pathway confers greater susceptibility to autism $(20-25,27)$.

For these reasons, we consider Het reeler mice, haploinsufficient for reelin and sharing some neurochemical and behavioral features with autistic patients, a suitable animal model for studying the effects of reelin deficiency in determining social communication deficits and in changing brain monoamine and brain metabolites levels. Unfortunately, no comparison can be drawn with homozygous mutant mice, since adult knockout reeler mice did not survive longer than weaning (79-82).

NO DEFICITS IN SOCIAL AND VOCAL REPERTOIRES DURING COURTSHIP To our knowledge, this is the first time that a detailed analysis of the adult male vocal repertoire has been performed in this mutant line. Only behavioral data on same-sex interactions or approaching/recognizing a conspecific have been collected $(44,51,52)$.

Recently, we characterized vocal and motor repertoires on homozygous and Het reeler pups (60) evidencing a general delay in vocal and motor development during the first 2 weeks of postnatal life, in line with the alterations in the same two systems observed in children with ASD. In addition, a preferential use of a specific call category (two-components) at pnd 2 and 6 was detected in both mutants (Het and homozygous), whereas an increased number of vocalizations characterized only Het pup's emission.

Contrary to what we found in pups, adult Het male mice did not show deficits on USVs emitted during courtship of a female in estrous. Social behaviors, generally associated to this vocal emission, were not affected either. These results are in contrast with the reduction in anogenital sniffing and/or the number of USVs found in other ASD animal models such as BTBR, En2, NMDANr1, NLG3, NLg4, Dlg4, and FmR1 mice (53, 83-87), but in line with data collected on Shank3 mice, carrying a mutation strongly implicated in autism and Phelan-McDermid 22q13 deletion syndrome, where male knockout mice did not present alterations in social communication and interaction (88).

These data thus confirm that adult Het reeler mice present deficits on cognitive performances but not on social domains (4447, 49-52). It is worth of notice that intellectual disabilities are present in about $50 \%$ of autistic individuals. Due to the cerebellar alteration leading to death shortly after weaning, no data could be collected on mice with the complete deletion in the reelin gene, thus we cannot exclude an impairment of the social domain only related to the complete deletion of reelin.

\section{OVER RESPONSE TO A MILD STRESS STIMULI}

Previous studies indicated that Het reeler mice have several abnormalities in their brain architecture (40-42), but, at a first sight, their phenotype is absolutely "normal" $(7,44,89)$. Some behavioral deficits become evident only after a "second hit" $(7,63,90,91)$ supporting the "double-hit" theory postulating a gene-environment interaction in the pathogenesis of several neurodevelopmental disorders such ASD (89). Depending on the features of environmental factors and the time-window of insult interacting with reelin expression, an individual could thus develop one neurodevelopmental disorder rather than another one (i.e., schizophrenia versus ASD).

Our previous evidence shows that either an environmental pollutant or, for example, an activated stress reactivity caused by repeated separation from the dams, elicits different responses as a function of the mouse genotype (91). In line with these data, in the present study, no significant genotype differences were found in basal activity levels of mice monitored in their home-cages for 1 week. By contrast, after a saline injection (a mild stressful stimulus), the Het male displayed a higher locomotor activity profile as compared to Wt male mice. Already in a previous study, our group showed a hyperactive profile in Het adolescent reeler mice following handling plus saline injections (63). Altogether, these data indicate that Het reeler mice show a different response to environmental stimuli, confirming the suitability of such mutant line for the study of gene-environment interactions $(7,92)$.

Moreover, a deficit in behavioral inhibition has been reported as a core alteration of Het reeler mice, associated with dysfunctions of mesolimbic DA transmission (93) and reduced GABAergic transmission in central nervous system $(40,94-96)$.

\section{IMPAIRMENT IN THE DOPAMINERGIC PATHWAY}

To correlate observed behavioral abnormalities to the neural systems reportedly affected by reelin mutation, we conducted HPLC analyses in different brain areas involved in autism, detecting impairments in the dopaminergic system. Specifically, Het reeler mice had decreased DA levels in cortex and increased levels in the olfactory bulb, whereas DA turnover was altered in cortex, bulb, and Hip.

A disruption of DA maturation in reelin haploinsufficient mice had been already suggested: a reduced locomotor activation by Damphetamine in reeler mice was associated with an exaggerated drug-induced stereotyped behavioral syndrome (90). Moreover, Ballmaier et al. (93) reported alterations in the mesolimbic DA pathway of Het reeler mice. In particular, they found that Het mice exhibit a reduction in DA transporter immunoreactivity and D2 receptor mRNA in the limbic striatum and the ventral tegmental area (93). In agreement with our study, they did not find any significant alteration in the dopaminergic markers examined in the nigrostriatal pathway of Het reeler mice.

Alterations in DA levels and its turnover have been found in brain areas primarily associated to reward. Individuals with ASD show reduced responsiveness to reward stimuli, a feature that appears to be especially prominent with social reinforces such as facial expressions, spoken language, and gestures $(97,98)$. No effects have been found in the striatum where DA contributes to motor performances. 
In addition, the neurotransmitter DA plays a pivotal modulatory role on executive functions and learning $(99,100)$, thus a dysfunctional DA system could underlying the cognitive deficits detected in Het mice.

\section{GLUTAMATE AND TAURINE INCREASED LEVELS IN HIPPOCAMPUS}

To gain deeper insights into the functional state of brain areas involved in ASD, we carried out a ${ }^{1} \mathrm{H}$ MRI guided spectroscopy examination in adult reeler mice. MRS is a powerful, non-invasive tool for monitoring neurological diseases (101) and it is also used in clinical studies on autistic individuals (102). Abnormalities in neurotransmitter pathways have been associated to ASD, with evidence for a possible implication of glutamatergic, GABAergic, and serotonergic imbalances (102).

In the Hip, as compared to Wt in Het mice, MRS showed increased levels of glutamate, taurine, phospho-creatine, and of the total amount of phospho-creatine plus creatine. Glutamate is the main brain excitatory neurotransmitter involved in cognitive functions, although in excessive quantities can cause neuronal damages typical of neurodegenerative diseases (for example, Alzheimer's and Huntington's diseases) (103-105). The higher levels of glutamate in the Hip of Het reeler mice are in agreement with previous findings reporting an increase of glutamate in Hip (106) and cortex (107) of ASD patients; altogether these evidences support the hypothesis of an imbalance between excitatory and inhibitory (GABA) systems as one of the possible causes of autism (107).

Recently, clinical trials with glutamate antagonists have been initiated, since they have been proved to be effective in rescuing social deficits and repetitive behaviors in selected animal models of autism (108). Also the presence of high levels of taurine in the Hip could be correlated to high levels of glutamate. In fact, taurine appears to have a protective action against glutamate excitotoxicity (109) and it is widely considered a general index of neuronal functionality.

The largest meta analysis performed on ASD patients showed evidence that ASD is characterized by age-dependent fluctuations in metabolite levels across the whole brain. In particular, significant reduction in the level of a cerebral metabolites, NAA, a specific neuronal marker, in whole gray matter of ASD children as well as significant increase in the total pool of creatine (phosphocreatine plus creatine) in adult subjects were observed (110). The observed differences in creatine as a function of age and brain region, suggest caution in the use of Cr-based ratio measures of metabolites. For this reason, we adopt a quantitative approach for brain metabolites level determination, which has been validated on phantom (111) as well as on other animal models of psychiatric and neurodevelopmental diseases (51, 112-114).

\section{CONCLUSION}

In the literature, Het reeler mice are widely considered a reliable animal model of either autism or schizophrenia. Genetic and molecular evidences showed that reelin messenger-RNA and its protein are downregulated in cortical, hippocampal, and cerebellar neurons of patients suffering of schizophrenia and autism $(3,8,10$, $20,115,116)$. In particular, these mutant mice are characterized by decreased contextual fear conditioning (48), prepulse inhibition $(43,117)$, impaired executive functions (45), and associative learning (48), all typical traits of schizophrenia. In addition, Het reeler mice yielded autistic-like deficits in social behavior and communication in the first two postnatal weeks of age (60) and perseverative (51) and hyperactive behaviors (44) at adulthood. Discordant evidences exist on this model, possibly associated with differences in the genetic background, age of mice, training and testing protocols, and rearing conditions $(52,89)$.

Overall, our results, together with data previously collected by our (Laviola and collaborators) and other groups suggest that Het reeler mice have common behavioral traits to both these neurodevelopmental disorders. Moreover, these studies indicate the suitability of this mutant line to investigate the role of reelin as vulnerability factor on the etiology of both disorders. In addition, Het reeler mutant mice may represent a useful animal model to develop novel treatment strategies for these devastating human disorders. For example, our HPLC and MRS results favor further studies to evaluate the effects of DA agonist or glutamate antagonist treatments on behavioral and neurochemical responses.

\section{ACKNOWLEDGMENTS}

Supported by the Italian Ministry of Health Grant (GR3), Young Researcher 2008, "Non-invasive tools for early detection of Autism Spectrum Disorders." We thank Flavia Chiarotti for the statistical advice.

\section{REFERENCES}

1. American Psychiatric Association, Washington D. Diagnostic and Statistical Manual of Mental Disorders DSM-5. Washington, DC: American Psychiatric Publishing (2013).

2. Impagnatiello F, Guidotti AR, Pesold C, Dwivedi Y, Caruncho H, Pisu MG, et al. A decrease of reelin expression as a putative vulnerability factor in schizophrenia. Proc Natl Acad Sci U S A (1998) 95:15718-23. doi:10.1073/pnas.95. 26.15718

3. Guidotti A, Auta J, Davis JM, Di-Giorgi-Gerevini V, Dwivedi Y, Grayson DR, et al. Decrease in reelin and glutamic acid decarboxylase67 (GAD67) expression in schizophrenia and bipolar disorder: a postmortem brain study. Arch Gen Psychiatry (2000) 57:1061-9. doi:10.1001/archpsyc.57.11.1061

4. Hong SE, Shugart YY, Huang DT, Shahwan SA, Grant PE, Hourihane JO, et al. Autosomal recessive lissencephaly with cerebellar hypoplasia is associated with human RELN mutations. Nat Genet (2000) 26:93-6. doi:10.1038/79246

5. Fatemi SH. Reelin mutations in mouse and man: from reeler mouse to schizophrenia, mood disorders, autism and lissencephaly. Mol Psychiatry (2001) 6:129-33. doi:10.1038/sj.mp.4000129

6. Keller F, Persico AM. The neurobiological context of autism. Mol Neurobiol (2003) 28:1-22. doi:10.1385/MN:28:1:1

7. Laviola G, Ognibene E, Romano E, Adriani W, Keller F. Gene-environment interaction during early development in the heterozygous reeler mouse: clues for modelling of major neurobehavioral syndromes. Neurosci Biobehav Rev (2009) 33:560-72. doi:10.1016/j.neubiorev.2008.09.006

8. Folsom TD, Fatemi SH. The involvement of Reelin in neurodevelopmental disorders. Neuropharmacology (2013) 68:122-35. doi:10.1016/j.neuropharm. 2012.08.015

9. Keller F, Persico AM, Zelante L, Gasperial P, D’agruma N, Maiorano N, et al. Reelin gene alleles and haplotypes are associated with autistic disorder. Society for Neuroscience. New Orleans (2000) 26:77 (31.11).

10. Fatemi SH, Stary JM, Halt AR, Realmuto GR. Dysregulation of Reelin and Bcl-2 proteins in autistic cerebellum. J Autism Dev Disord (2001) 31:529-35. doi:10.1023/A:1013234708757

11. Fatemi SH, Stary JM, Egan EA. Reduced blood levels of reelin as a vulnerability factor in pathophysiology of autistic disorder. Cell Mol Neurobiol (2002) 22:139-52. doi:10.1023/A:1019857620251

12. Fatemi SH, Snow AV, Stary JM, Araghi-Niknam M, Reutiman TJ, Lee S, et al. Reelin signaling is impaired in autism. Biol Psychiatry (2005) 57:777-87. doi:10.1016/j.biopsych.2004.12.018 
13. Krebs MO, Betancur C, Leroy S, Bourdel MC, Gillberg C, Leboyer M. Absence of association between a polymorphic GGC repeat in the 5' untranslated region of the reelin gene and autism. Mol Psychiatry (2002) 7:801-4. doi:10.1038/sj.mp.4001071

14. Zhang H, Liu X, Zhang C, Mundo E, Macciardi F, Grayson DR, et al. Reelin gene alleles and susceptibility to autism spectrum disorders. Mol Psychiatry (2002) 7:1012-7. doi:10.1038/sj.mp.4001124

15. Bonora E, Beyer KS, Lamb JA, Parr JR, Klauck SM, Benner A, et al. Analysis of reelin as a candidate gene for autism. Mol Psychiatry (2003) 8:885-92. doi:10.1038/sj.mp.4001310

16. Serajee FJ, Zhong H, Mahbubul Huq AH. Association of Reelin gene polymorphisms with autism. Genomics (2006) 87:75-83. doi:10.1016/j.ygeno. 2005.09.008

17. Dutta S, Guhathakurta S, Sinha S, Chatterjee A, Ahmed S, Ghosh S, et al. Reelin gene polymorphisms in the Indian population: a possible paternal 5'UTRCGG-repeat-allele effect on autism. Am J Med Genet B Neuropsychiatr Genet (2007) 144B:106-12. doi:10.1002/ajmg.b.30419

18. Dutta S, Sinha S, Ghosh S, Chatterjee A, Ahmed S, Usha R. Genetic analysis of reelin gene (RELN) SNPs: no association with autism spectrum disorder in the Indian population. Neurosci Lett (2008) 441:56-60. doi:10.1016/j.neulet.2008. 06.022

19. He Y, Xun G, Xia K, Hu Z, Lv L, Deng Z, et al. No significant association between RELN polymorphism and autism in case-control and family-based association study in Chinese Han population. Psychiatry Res (2011) 187:462-4. doi:10.1016/j.psychres.2010.04.051

20. Persico AM, D’agruma L, Maiorano N, Totaro A, Militerni R, Bravaccio C, et al. Reelin gene alleles and haplotypes as a factor predisposing to autistic disorder. Mol Psychiatry (2001) 6:150-9. doi:10.1038/sj.mp.4000850

21. Skaar DA, Shao Y, Haines JL, Stenger JE, Jaworski J, Martin ER, et al. Analysis of the RELN gene as a genetic risk factor for autism. Mol Psychiatry (2005) 10:563-71. doi:10.1038/si.mp.4001614

22. Ashley-Koch AE, Jaworski J, Ma De Q, Mei H, Ritchie MD, Skaar DA, et al. Investigation of potential gene-gene interactions between APOE and RELN contributing to autism risk. Psychiatr Genet (2007) 17:221-6. doi:10.1097/ YPG.0b013e32809c2f75

23. Li H, Li Y, Shao J, Li R, Qin Y, Xie C, et al. The association analysis of RELN and GRM8 genes with autistic spectrum disorder in Chinese Han population. Am J Med Genet B Neuropsychiatr Genet (2008) 147B:194-200. doi:10.1002/ajmg.b.30584

24. Holt R, Barnby G, Maestrini E, Bacchelli E, Brocklebank D, Sousa I, et al. Linkage and candidate gene studies of autism spectrum disorders in European populations. Eur J Hum Genet (2010) 18:1013-9. doi:10.1038/ejhg.2010.69

25. Fu X, Mei Z, Sun L. Association between the g.296596G > A genetic variant of RELN gene and susceptibility to autism in a Chinese Han population. Genet Mol Biol (2013) 36:486-9. doi:10.1590/S1415-47572013005000037

26. Sharma JR, Arieff Z, Gameeldien H, Davids M, Kaur M, Van Der Merwe L. Association analysis of two single-nucleotide polymorphisms of the RELN gene with autism in the South African population. Genet Test Mol Biomarkers (2013) 17:93-8. doi:10.1089/gtmb.2012.0212

27. Wang Z, Hong Y, Zou L, Zhong R, Zhu B, Shen N, et al. Reelin gene variants and risk of autism spectrum disorders: an integrated meta-analysis. Am J Med Genet B Neuropsychiatr Genet (2014) 165B:192-200. doi:10.1002/ajmg.b.32222

28. Hamburgh M. Analysis of the postnatal developmental effects of "reeler," a neurological mutation in mice. A study in developmental genetics. Dev Biol (1963) 8:165-85. doi:10.1016/0012-1606(63)90040-X

29. Tissir F, Goffinet AM. Reelin and brain development. Nat Rev Neurosci (2003) 4:496-505. doi:10.1038/nrn1113

30. Boyle MP, Bernard A, Thompson CL, Ng L, Boe A, Mortrud M, et al. Cell-typespecific consequences of Reelin deficiency in the mouse neocortex, hippocampus, and amygdala. J Comp Neurol (2011) 519:2061-89. doi:10.1002/cne.22655

31. Mariani J, Crepel F, Mikoshiba K, Changeux JP, Sotelo C. Anatomical, physiological and biochemical studies of the cerebellum from Reeler mutant mouse. Philos Trans R Soc Lond B Biol Sci (1977) 281:1-28. doi:10.1098/rstb.1977.0121

32. Bailey AJ. The biology of autism. Psychol Med (1993) 23:7-11. doi:10.1017/ S0033291700038794

33. Casanova MF, Buxhoeveden DP, Switala AE, Roy E. Minicolumnar pathology in autism. Neurology (2002) 58:428-32. doi:10.1212/WNL.58.3.428
34. Courchesne E, Carper R, Akshoomoff N. Evidence of brain overgrowth in the first year of life in autism. JAMA (2003) 290:337-44. doi:10.1001/jama. 290.3.337

35. Palmen SJ, Van Engeland H, Hof PR, Schmitz C. Neuropathological findings in autism. Brain (2004) 127:2572-83. doi:10.1093/brain/awh287

36. Bauman ML, Kemper TL. Neuroanatomic observations of the brain in autism: a review and future directions. Int J Dev Neurosci (2005) 23:183-7. doi:10.1016/j.ijdevneu.2004.09.006

37. Wegiel J, Kuchna I, Nowicki K, Imaki H, Wegiel J, Marchi E, et al. The neuropathology of autism: defects of neurogenesis and neuronal migration, and dysplastic changes. Acta Neuropathol (2010) 119:755-70. doi:10.1007/s00401010-0655-4

38. Schumann CM, Nordahl CW. Bridging the gap between MRI and postmortem research in autism. Brain Res (2011) 1380:175-86. doi:10.1016/j. brainres.2010.09.061

39. Fatemi SH, Aldinger KA, Ashwood P, Bauman ML, Blaha CD, Blatt GJ, et al. Consensus paper: pathological role of the cerebellum in autism. Cerebellum (2012) 11:777-807. doi:10.1007/s12311-012-0355-9

40. Biamonte F, Assenza G, Marino R, D’amelio M, Panteri R, Caruso D, et al. Interactions between neuroactive steroids and reelin haploinsufficiency in Purkinje cell survival. Neurobiol Dis (2009) 36:103-15. doi:10.1016/j.nbd.2009. 07.001

41. Maloku E, Covelo IR, Hanbauer I, Guidotti A, Kadriu B, Hu Q, et al. Lower number of cerebellar Purkinje neurons in psychosis is associated with reduced reelin expression. Proc Natl Acad Sci U S A (2010) 107:4407-11. doi:10.1073/pnas.0914483107

42. Pappas GD, Kriho V, Pesold C. Reelin in the extracellular matrix and dendritic spines of the cortex and hippocampus: a comparison between wild type and heterozygous reeler mice by immunoelectron microscopy. J Neurocytol (2001) 30:413-25. doi:10.1023/A:1015017710332

43. Tueting P, Costa E, Dwivedi Y, Guidotti A, Impagnatiello F, Manev R, et al. The phenotypic characteristics of heterozygous reeler mouse. Neuroreport (1999) 10:1329-34. doi:10.1097/00001756-199904260-00032

44. Ognibene E, Adriani W, Granstrem O, Pieretti S, Laviola G. Impulsivityanxiety-related behavior and profiles of morphine-induced analgesia in heterozygous reeler mice. Brain Res (2007) 1131:173-80. doi:10.1016/j.brainres. 2006.11.007

45. Krueger DD, Howell JL, Hebert BF, Olausson P, Taylor JR, Nairn AC. Assessment of cognitive function in the heterozygous reeler mouse. Psychopharmacology (Berl) (2006) 189:95-104. doi:10.1007/s00213-006-0530-0

46. Brigman JL, Padukiewicz KE, Sutherland ML, Rothblat LA. Executive functions in the heterozygous reeler mouse model of schizophrenia. Behav Neurosci (2006) 120:984-8. doi:10.1037/0735-7044.120.4.984

47. Marrone MC, Marinelli S, Biamonte F, Keller F, Sgobio CA, Ammassari-Teule $\mathrm{M}$, et al. Altered cortico-striatal synaptic plasticity and related behavioura impairments in reeler mice. Eur J Neurosci (2006) 24:2061-70. doi:10.1111/ j.1460-9568.2006.05083.x

48. Qiu S, Korwek KM, Pratt-Davis AR, Peters M, Bergman MY, Weeber EJ. Cognitive disruption and altered hippocampus synaptic function in Reelin haploinsufficient mice. Neurobiol Learn Mem (2006) 85:228-42. doi:10.1016/j.nlm. 2005.11.001

49. Larson J, Hoffman JS, Guidotti A, Costa E. Olfactory discrimination learning deficit in heterozygous reeler mice. Brain Res (2003) 971:40-6. doi:10.1016/ S0006-8993(03)02353-9

50. Ammassari-Teule M, Sgobio C, Biamonte F, Marrone C, Mercuri NB, Keller F. Reelin haploinsufficiency reduces the density of PV+ neurons in circumscribed regions of the striatum and selectively alters striatal-based behaviors. Psychopharmacology (Berl) (2009) 204:511-21. doi:10.1007/s00213-009-1483-x

51. Macri S, Biamonte F, Romano E, Marino R, Keller F, Laviola G. Perseverative responding and neuroanatomical alterations in adult heterozygous reeler mice are mitigated by neonatal estrogen administration. Psychoneuroendocrinology (2010) 35:1374-87. doi:10.1016/j.psyneuen.2010.03.012

52. Podhorna J, Didriksen M. The heterozygous reeler mouse: behavioural phenotype. Behav Brain Res (2004) 153:43-54. doi:10.1016/j.bbr.2003.10.033

53. Scattoni ML, Ricceri L, Crawley JN. Unusual repertoire of vocalizations in adult BTBR T+tf/J mice during three types of social encounters. Genes Brain Behav (2011) 10:44-56. doi:10.1111/j.1601-183X.2010.00623.x 
54. Liu X, Hubbard JA, Fabes RA, Adam JB. Sleep disturbances and correlates of children with autism spectrum disorders. Child Psychiatry Hum Dev (2006) 37:179-91. doi:10.1007/s10578-006-0028-3

55. Malow BA, Marzec ML, Mcgrew SG, Wang L, Henderson LM, Stone WL. Characterizing sleep in children with autism spectrum disorders: a multidimensional approach. Sleep (2006) 29:1563-71.

56. Goldman SE, Surdyka K, Cuevas R, Adkins K, Wang L, Malow BA. Defining the sleep phenotype in children with autism. Dev Neuropsychol (2009) 34:560-73. doi:10.1080/87565640903133509

57. May T, Cornish K, Conduit R, Rajaratnam SM, Rinehart NJ. Sleep in highfunctioning children with autism: longitudinal developmental change and associations with behavior problems. Behav Sleep Med (2013). doi:10.1080/ 15402002.2013.829064

58. Rugh R. The Mouse: Its Reproduction and Development. New York: Oxford University Press (1990).

59. Scattoni ML, Gandhy SU, Ricceri L, Crawley JN. Unusual repertoire of vocalizations in the BTBR T+tf/J mouse model of autism. PLoS One (2008) 3:e3067. doi:10.1371/journal.pone.0003067

60. Romano E, Michetti C, Caruso A, Laviola G, Scattoni ML. Characterization of neonatal vocal and motor repertoire of reelin mutant mice. PLoS One (2013) 8:e64407. doi:10.1371/journal.pone.0064407

61. Dell'Omo G, Vannoni E, Vyssotski AL, Di Bari MA, Nonno R, Agrimi U, et al. Early behavioural changes in mice infected with BSE and scrapie: automated home cage monitoring reveals prion strain differences. Eur J Neurosci (2002) 16:735-42. doi:10.1046/j.1460-9568.2002.02128.x

62. Adriani W, Caprioli A, Granstrem O, Carli M, Laviola G. The spontaneously hypertensive-rat as an animal model of ADHD: evidence for impulsive and non-impulsive subpopulations. Neurosci Biobehav Rev (2003) 27:639-51. doi:10.1016/j.neubiorev.2003.08.007

63. Romano E, Fuso A, Laviola G. Nicotine restores Wt-like levels of reelin and GAD67 gene expression in brain of heterozygous reeler mice. Neurotox Res (2013) 24:205-15. doi:10.1007/s12640-013-9378-3

64. Cassano T, Gaetani S, Morgese MG, Macheda T, Laconca L, Dipasquale P, et al Monoaminergic changes in locus coeruleus and dorsal raphe nucleus following noradrenaline depletion. Neurochem Res (2009) 34:1417-26. doi:10.1007/ s11064-009-9928-5

65. Paxinos G, Franklin K. The Mouse Brain in Stereotaxic Coordinates. San Diego: Elsevier Academic Press (2001).

66. Canese R, Pisanu ME, Mezzanzanica D, Ricci A, Paris L, Bagnoli M, et al. Characterisation of in vivo ovarian cancer models by quantitative $1 \mathrm{H}$ magnetic resonance spectroscopy and diffusion-weighted imaging. NMR Biomed (2012) 25:632-42. doi:10.1002/nbm.1779

67. Provencher SW. Estimation of metabolite concentrations from localized in vivo proton NMR spectra. Magn Reson Med (1993) 30:672-9. doi:10.1002/mrm. 1910300604

68. Johnson KP, Giannotti F, Cortesi F. Sleep patterns in autism spectrum disorders. Child Adolesc Psychiatr Clin N Am (2009) 18:917-28. doi:10.1016/j.chc. 2009.04.001

69. Glickman G. Circadian rhythms and sleep in children with autism. Neurosci Biobehav Rev (2010) 34:755-68. doi:10.1016/j.neubiorev.2009.11.017

70. Rzepecka H, Mckenzie K, Mcclure I, Murphy S. Sleep, anxiety and challenging behaviour in children with intellectual disability and/or autism spectrum disorder. Res Dev Disabil (2011) 32:2758-66. doi:10.1016/j.ridd.2011.05.034

71. Kotagal S, Broomall E. Sleep in children with autism spectrum disorder. Pediatr Neurol (2012) 47:242-51. doi:10.1016/j.pediatrneurol.2012.05.007

72. Fonken LK, Finy MS, Walton JC, Weil ZM, Workman JL, Ross J, et al. Influence of light at night on murine anxiety- and depressive-like responses. Behav Brain Res (2009) 205:349-54. doi:10.1016/j.bbr.2009.07.001

73. Menet JS, Rosbash M. When brain clocks lose track of time: cause or consequence of neuropsychiatric disorders. Curr Opin Neurobiol (2011) 21:849-57. doi:10.1016/j.conb.2011.06.008

74. Griesauer I, Diao W, Ronovsky M, Elbau I, Sartori S, Singewald N, et al. Circadian abnormalities in a mouse model of high trait anxiety and depression. Ann Med (2014) 46:148-54. doi:10.3109/07853890.2013.866440

75. Badea A, Nicholls PJ, Johnson GA, Wetsel WC. Neuroanatomical phenotypes in the reeler mouse. Neuroimage (2007) 34:1363-74. doi:10.1016/j.neuroimage. 2006.09.053
76. Niu S, Renfro A, Quattrocchi CC, Sheldon M, D’Arcangelo G. Reelin promotes hippocampal dendrite development through the VLDLR/ApoER2-Dab1 pathway. Neuron (2004) 41:71-84. doi:10.1016/S0896-6273(03)00819-5

77. Stranahan AM, Erion JR, Wosiski-Kuhn M. Reelin signaling in development, maintenance, and plasticity of neural networks. Ageing Res Rev (2013) 12:815-22. doi:10.1016/j.arr.2013.01.005

78. Costa E, Davis J, Grayson DR, Guidotti A, Pappas GD, Pesold C. Dendritic spine hypoplasticity and downregulation of reelin and GABAergic tone in schizophrenia vulnerability. Neurobiol Dis (2001) 8:723-42. doi:10.1006/nbdi. 2001.0436

79. Falconer DS. Two new mutants, 'trembler' and 'reeler', with neurological actions in the house mouse (Mus musculus L.). J Genet (1951) 50:192-201. doi:10.1007/BF02996215

80. Caviness VS Jr, Sidman RL. Time of origin or corresponding cell classes in the cerebral cortex of normal and reeler mutant mice: an autoradiographic analysis. J Comp Neurol (1973) 148:141-51. doi:10.1002/cne.901480202

81. Goffinet AM. An early development defect in the cerebral cortex of the reeler mouse. A morphological study leading to a hypothesis concerning the action of the mutant gene. Anat Embryol (Berl) (1979) 157:205-16. doi:10.1007/BF00305160

82. D'Arcangelo G, Curran T. Reeler: new tales on an old mutant mouse. Bioessays (1998) 20:235-44. doi:10.1002/(SICI) 1521-1878(199803)20:3<235::AIDBIES7>3.0.CO;2-Q

83. Jamain S, Radyushkin K, Hammerschmidt K, Granon S, Boretius S, Varoqueaux $\mathrm{F}$, et al. Reduced social interaction and ultrasonic communication in a mouse model of monogenic heritable autism. Proc Natl Acad Sci U S A (2008) 105:1710-5. doi:10.1073/pnas.0711555105

84. Radyushkin K, Hammerschmidt K, Boretius S, Varoqueaux F, El-Kordi A, Ronnenberg A, et al. Neuroligin-3-deficient mice: model of a monogenic heritable form of autism with an olfactory deficit. Genes Brain Behav (2009) 8:416-25. doi:10.1111/j.1601-183X.2009.00487.x

85. Brielmaier J, Matteson PG, Silverman JL, Senerth JM, Kelly S, Genestine M, et al. Autism-relevant social abnormalities and cognitive deficits in engrailed-2 knockout mice. PLoS One (2012) 7:e40914. doi:10.1371/journal.pone.0040914

86. Gandal MJ, Anderson RL, Billingslea EN, Carlson GC, Roberts TP, Siegel SJ. Mice with reduced NMDA receptor expression: more consistent with autism than schizophrenia? Genes Brain Behav (2012) 11:740-50. doi:10.1111/j.1601183X.2012.00816.x

87. Rotschafer SE, Trujillo MS, Dansie LE, Ethell IM, Razak KA. Minocycline treatment reverses ultrasonic vocalization production deficit in a mouse model of Fragile X Syndrome. Brain Res (2012) 1439:7-14. doi:10.1016/j.brainres.2011. 12.041

88. Yang M, Bozdagi O, Scattoni ML, Wohr M, Roullet FI, Katz AM, et al. Reduced excitatory neurotransmission and mild autism-relevant phenotypes in adolescent Shank3 null mutant mice. J Neurosci (2012) 32:6525-41. doi:10.1523/ JNEUROSCI.6107-11.2012

89. Salinger WL, Ladrow P, Wheeler C. Behavioral phenotype of the reeler mutant mouse: effects of RELN gene dosage and social isolation. Behav Neurosci (2003) 117:1257-75. doi:10.1037/0735-7044.117.6.1257

90. Laviola G, Adriani W, Gaudino C, Marino R, Keller F. Paradoxical effects of prenatal acetylcholinesterase blockade on neuro-behavioral development and drug-induced stereotypies in reeler mutant mice. Psychopharmacology (Berl) (2006) 187:331-44. doi:10.1007/s00213-006-0426-z

91. Ognibene E, Adriani W, Macri S, Laviola G. Neurobehavioural disorders in the infant reeler mouse model: interaction of genetic vulnerability and consequences of maternal separation. Behav Brain Res (2007) 177:142-9. doi:10.1016/j.bbr.2006.10.027

92. Ognibene E, Adriani W, Caprioli A, Ghirardi O, Ali SF, Aloe L, et al. The effect of early maternal separation on brain derived neurotrophic factor and monoamine levels in adult heterozygous reeler mice. Prog Neuropsychopharmacol Biol Psychiatry (2008) 32:1269-76. doi:10.1016/j.pnpbp.2008.03.023

93. Ballmaier M, Zoli M, Leo G, Agnati LF, Spano P. Preferential alterations in the mesolimbic dopamine pathway of heterozygous reeler mice: an emerging animal-based model of schizophrenia. Eur J Neurosci (2002) 15:1197-205. doi:10.1046/j.1460-9568.2002.01952.x

94. Owens DF, Kriegstein AR. Is there more to GABA than synaptic inhibition? Nat Rev Neurosci (2002) 3:715-27. doi:10.1038/nrn919 
95. Watanabe M, Maemura K, Kanbara K, Tamayama T, Hayasaki H. GABA and GABA receptors in the central nervous system and other organs. Int Rev Cytol (2002) 213:1-47. doi:10.1016/S0074-7696(02)13011-7

96. Wang L, Bruce G, Spary E, Deuchars J, Deuchars SA. GABA(B) mediated regulation of sympathetic preganglionic neurons: pre- and postsynaptic sites of action. Front Neurol (2010) 1:142. doi:10.3389/fneur.2010.00142

97. Dawson G, Webb SJ, Mcpartland J. Understanding the nature of face processing impairment in autism: insights from behavioral and electrophysiological studies. Dev Neuropsychol (2005) 27:403-24. doi:10.1207/s15326942dn2703_6

98. Schultz RT. Developmental deficits in social perception in autism: the role of the amygdala and fusiform face area. Int J Dev Neurosci (2005) 23:125-41. doi:10.1016/j.ijdevneu.2004.12.012

99. Pezze MA, Feldon J. Mesolimbic dopaminergic pathways in fear conditioning Prog Neurobiol (2004) 74:301-20. doi:10.1016/j.pneurobio.2004.09.004

100. Rinaldi A, Mandillo S, Oliverio A, Mele A. D1 and D2 receptor antagonist injections in the prefrontal cortex selectively impair spatial learning in mice. Neuropsychopharmacology (2007) 32:309-19. doi:10.1038/sj.npp.1301176

101. Tran T, Ross B, Lin A. Magnetic resonance spectroscopy in neurological diagnosis. Neurol Clin (2009) 27:21-60,xiii. doi:10.1016/j.ncl.2008.09.007

102. Chugani DC. Neuroimaging and neurochemistry of autism. Pediatr Clin North Am (2012) 59:63-73,x. doi:10.1016/j.pcl.2011.10.002

103. Olney JW, de Gubareff T. Glutamate neurotoxicity and Huntington's chorea. Nature (1978) 271:557-9. doi:10.1038/271557a0

104. Tsai VW, Scott HL, Lewis RJ, Dodd PR. The role of group I metabotropic glutamate receptors in neuronal excitotoxicity in Alzheimer's disease. Neurotox Res (2005) 7:125-41. doi:10.1007/BF03033782

105. Estrada-Sanchez AM, Montiel T, Segovia J, Massieu L. Glutamate toxicity in the striatum of the R6/2 Huntington's disease transgenic mice is age-dependent and correlates with decreased levels of glutamate transporters. Neurobiol Dis (2009) 34:78-86. doi:10.1016/j.nbd.2008.12.017

106. Page LA, Daly E, Schmitz N, Simmons A, Toal F, Deeley Q, et al. In vivo $1 \mathrm{H}$ magnetic resonance spectroscopy study of amygdala-hippocampal and parietal regions in autism. Am J Psychiatry (2006) 163:2189-92. doi:10.1176/appi.ajp. 163.12.2189

107. Bejjani A, O’neill J, Kim JA, Frew AJ, Yee VW, Ly R, et al. Elevated glutamatergic compounds in pregenual anterior cingulate in pediatric autism spectrum disorder demonstrated by 1H MRS and 1H MRSI. PLoS One (2012) 7:e38786. doi:10.1371/journal.pone.0038786

108. Silverman JL, Smith DG, Rizzo SJ, Karras MN, Turner SM, Tolu SS, et al. Negative allosteric modulation of the mGluR5 receptor reduces repetitive behaviors and rescues social deficits in mouse models of autism. Sci Transl Med (2012) 4:131ra151. doi:10.1126/scitranslmed.3003501

109. Wu JY, Wu H, Jin Y, Wei J, Sha D, Prentice H, et al. Mechanism of neuroprotective function of taurine. Adv Exp Med Biol (2009) 643:169-79. doi:10.1007/978-0-387-75681-3 17

110. Ipser JC, Syal S, Bentley J, Adnams CM, Steyn B, Stein DJ. 1H-MRS in autism spectrum disorders: a systematic meta-analysis. Metab Brain Dis (2012) 27:275-87. doi:10.1007/s11011-012-9293-y
111. Canese R, Pisanu ME, Mezzanzanica D, Ricci A, Paris L, Bagnoli M, et al. Characterisation of in vivo ovarian cancer models by quantitative $1 \mathrm{H}$ magnetic resonance spectroscopy and diffusion-weighted imaging. NMR Biomed (2011) 25:632-42. doi:10.1002/nbm.1779

112. Adriani W, Canese R, Podo F, Laviola G. 1H MRS-detectable metabolic brain changes and reduced impulsive behavior in adult rats exposed to methylphenidate during adolescence. Neurotoxicol Teratol (2007) 29:116-25. doi:10.1016/j.ntt.2006.11.010

113. Marco EM, Adriani W, Canese R, Podo F, Viveros MP, Laviola G. Enhancement of endocannabinoid signalling during adolescence: modulation of impulsivity and long-term consequences on metabolic brain parameters in early maternally deprived rats. Pharmacol Biochem Behav (2007) 86:334-45. doi:10.1016/j.pbb.2006.10.006

114. De Filippis B, Fabbri A, Simone D, Canese R, Ricceri L, Malchiodi-Albedi F, et al. Modulation of RhoGTPases improves the behavioral phenotype and reverses astrocytic deficits in a mouse model of Rett syndrome. Neuropsychopharmacology (2011) 37:1152-63. doi:10.1038/npp.2011.301

115. Fatemi SH, Stary JM, Earle JA, Araghi-Niknam M, Eagan E. GABAergic dysfunction in schizophrenia and mood disorders as reflected by decreased levels of glutamic acid decarboxylase 65 and $67 \mathrm{kDa}$ and Reelin proteins in cerebellum. Schizophr Res (2005) 72:109-22. doi:10.1016/j.schres. 2004.02.017

116. Eastwood SL, Harrison PJ. Cellular basis of reduced cortical reelin expression in schizophrenia. Am J Psychiatry (2006) 163:540-2. doi:10.1176/appi.ajp.163. 3.540

117. Tremolizzo L, Carboni G, Ruzicka WB, Mitchell CP, Sugaya I, Tueting P, et al. An epigenetic mouse model for molecular and behavioral neuropathologies related to schizophrenia vulnerability. Proc Natl Acad Sci U S A (2002) 99:17095-100. doi:10.1073/pnas.262658999

Conflict of Interest Statement: The authors declare that the research was conducted in the absence of any commercial or financial relationships that could be construed as a potential conflict of interest.

Received: 07 June 2014; accepted: 21 August 2014; published online: 04 September 2014. Citation: Michetti C, Romano E, Altabella L, Caruso A, Castelluccio P, Bedse G, Gaetani S, Canese R, Laviola G and Scattoni ML (2014) Mapping pathological phenotypes in reelin mutant mice. Front. Pediatr. 2:95. doi: 10.3389/fped.2014.00095

This article was submitted to Child and Neurodevelopmental Psychiatry, a section of the journal Frontiers in Pediatrics.

Copyright (c) 2014 Michetti, Romano, Altabella, Caruso, Castelluccio, Bedse, Gaetani, Canese, Laviola and Scattoni. This is an open-access article distributed under the terms of the Creative Commons Attribution License (CC BY). The use, distribution or reproduction in other forums is permitted, provided the original author(s) or licensor are credited and that the original publication in this journal is cited, in accordance with accepted academic practice. No use, distribution or reproduction is permitted which does not comply with these terms. 